\title{
Richard Holloway, Mică istorie a religiei, trad. Diana Popescu-Marin, Bucureşti, Editura Litera, 2021, 368 p.
}

Richard Holloway este scriitor, realizator radio şi cleric scoţian. A fost Episcop de Edinburgh între anii 19862000 şi Primat al Bisericii

RICHARD HOLLOWAY

MIC $\breve{A}$
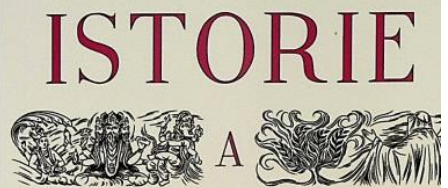

RELIGIEI

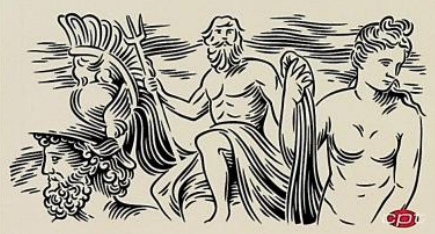

Episcopale Scoţiene între anii 19922000. Prima ediţie a cărţii Mică istorie a religiei a apărut în anul 2016, la Editura Universităţii Yale din New Haven, Connecticut, SUA, urmând ca cinci ani mai târziu, în anul 2021, cartea să apară şi în limba română sub egida Editurii Litera din Bucureşti.

Structurată în 40 de capitole, precedate de un cuprins şi încheiate cu un indice onomastic, cartea lui Richard Holloway sintetizează, în mai puţin de 400 de pagini, istoria religioasă a omenirii încă din preistorie, deoarece „dovezile privind unele practici religioase datează de circa 130000 de ani înainte de era creştină şi sunt legate de felul în care strămoşii noştri îşi îngropau morţii” (p. 13), şi până în anul precedent publicării iniţiale a acestei cărţi, anul 2015, mai exact, până în luna octombrie a acestui an, când a avut loc, la Salt Lake City, în Utah, SUA, 
Adunarea Parlamentului Mondial al Religiilor, promotorul „unirii religiilor lumii sub un nou tip de ecumenism global" (p. 331).

Probabil că, cel puţin din punct de vedere istoric, cel mai remarcabil aspect al lucrării lui Holloway, observat pe parcursul celor 40 de capitole, este dorinţa acestuia de a prezenta istoria religiei într-o manieră cât se poate de cronologică, dorinţă care s-a şi concretizat în cele din urmă în lucrare. Mai exact, Holloway nu abordează într-o manieră monografică sau, altfel spus, pe parcursul unui capitol sau pe parcursul mai multor capitole succesive, fiecare religie sau fiecare mişcare religioasă, apărută în cadrul unei religii, de care aminteşte în cuprinsul lucrării sale, ci el, din dorinţa de a fi mai degrabă un veritabil istoric, decât un bun taxonomist, preferă să expună totul într-o manieră din care sincopele geografice ale religiei nu pot fi excluse, iar aceasta tocmai în intenţia de a-i oferi cititorului un parcurs istoric narativ care să îl ajute pe acesta atât să îşi clarifice anumite aspect legate de religie, în general, şi de diferitele religii, în special, cât şi să dobândească noi cunoştinţe religioase pe teritoriul unor religii despre care foarte probabil că respectivul credea că le-a explorat deja suficient. Aşadar, în cartea lui Holloway, din intenţia de a respecta firul istoric al religiei, vom face salturi în spaţiu, purtaţi fiind pe aproape toate continentele lumii, din Africa în Asia şi din Europa în America.

După ce în primul capitol al cărţii vorbeşte despre rădăcinile preistorice ale religiei, în al doilea capitol al acesteia Holloway nu începe să abordeaze, cum probabil deja erau obişnuiţi cei interesaţi de istorie, în general, şi de istoria religiilor, în special, primele forme de religii politeiste orientale, ci el trece direct la momentul revelaţiei din rugul care ardea şi nu se mistuia, revelaţia lui Dumnezeu către Moise, moment pe care îl consideră, pe bună dreptate, a fi unul dintre cele mai importante puncte de cotitură în istoria religioasă monoteistă a întregii lumi. $\mathrm{Cu}$ toate acestea, în următoarele două capitole ale cărţii, Holloway îşi îndreaptă atenţia asupra hinduismului, continuând pe această linie religioasă indiană cu alte două religii care au apărut în acest areal teritorial: buddhismul, în capitolul cinci, apoi jainismul, în capitolul şase. Din jainism, Holloway preia conceptul religios de anekantavada, 
potrivit căruia jainiştii „,chiar şi la nivel mental, nu îşi puteau permite să comite acte răuvoitoare, fiind obligaţi să acţioneze nonviolent. Aceştia respectau diferitele moduri în care oamenii vedeau şi experimentau realitatea, recunoscând, în acelaşi timp, faptul că nimeni nu vedea realitatea la adevăratele dimensiuni. Iar pentru a ilustra această doctrină a respectului, jainiştii au creat o poveste despre şase orbi care au fost invitaţi să descrie un elefant atingând diferite părţi ale corpului acestuia” (p. 58). Într-o manieră similar vede Holloway conceptul de religie, ca fiind elefantul, în timp ce conceptul de religii sunt membrele acestuia, iar orbii sunt, în această situaţie, toţi cei afiliaţi sentimentului religios. Pilda jainistă cu cei şase orbi şi cu elefantul va fi reluată de două ori pe parcursul cărţii.

De la capitolul şapte şi până la capitolul doisprezece este tratată istoria religioasă a poporului evreu, începând de la Avraam, revenind la Moise şi terminând cu distrugerea Ierusalimului de către romani în anul 70 d. Hr. Deşi, Holloway începe relatarea despre poporul evreu într-o manieră istorică şi biblică cronologică, de la Avraam, strămoşul celor trei religii monoteiste, revenind la Moise, la regi, la profeţi şi până în primul secol din era noastră, totuşi, el îşi încheie capitolul $12 \mathrm{cu}$ exemplul lui Iov, în persoana căruia vede întruchipat întregul popor evreu încă de la începuturile sale, trecând prin toate vicisitudinile istoriei şi până la fericita sa restaurare de la sfârşitul lumii. Iar mesajul Cărţii lui Iov s-ar putea sintetiza, în opinia lui Holloway, în următoarea propoziţie: „Nu fi atât de convins că ştii cine este Dumnezeu şi care este planul Lui” (p. 111)... atât cu tine, cât şi cu cei din jur, s-ar mai putea adăuga.

În capitolele 13-16 suntem purtaţi mult mai departe în spaţiu, deşi rămânem încă în aceleaşi borne temporale ale ultimei jumătăţi a mileniului I î. Hr. Holloway se ocupă în aceste patru capitole de patru dintre cele mai vechi religii orientale, religii care încă mai există şi astăzi: zoroastrismul dualist apărut în Iran, confucianismul şi taoismul apărute în China, precum şi shintoismul apărut în Japonia. Despre cele trei din urmă, autorul face corecta observaţie că ele sunt foarte întipărite nu numai în modul strict spiritual şi religios de existenţă al chinezilor şi al japonezilor, ci şi în modul lor 
cotidian şi social de existenţă. Din această cauză, buddhismul, odată ajuns în cele două ţări, a prins în acestea rădăcini puternice, convieţuind şi influenţând puternic şi religiile locale. În capitolul 17, păstrând încă, parţial, izul religios asiatic, se revine în Europa, în Grecia şi în Roma antică, unde apar religiile de mistere, precum Misterele de la Eleusis şi Misterele lui Mithra, care, subliniază Holloway, ,apelau la emoţii. Nu era ceva ce puteai învăţa. Era ceva ce simţeai. Această experienţă era transformatoare” (p. 153).

Ajuns cu relatarea istoriei religiei la cumpăna dintre cele două ere, Holloway procedează în capitolul 18 la fel precum a procedat şi în capitolul 2. Mai exact, începând să vorbească în lucrarea sa despre creştinism, de la capitolul 18 şi până la capitolul 21, într-o primă fază, el începe relatarea cu persoana Sfântului Apostol Pavel, nu cu cea a lui Iisus Hristos, întocmai precum în cazul iudaismului care şi-a început relatarea cu Moise, nu cu Avraam. Iar dacă pentru Moise, în devenirea sa religioasă, un rol important 1-a jucat revelaţia rugului care ardea, dar nu se mistuia de pe Muntele Horeb, pentru Sfântul Apostol Pavel acest rol important în devenirea sa religioasă, ori, mai corect spus, în transformarea sa religioasă, a fost îndeplinit de convertirea de pe drumul Damascului. $\mathrm{Cu}$ toate acestea, Holloway se raliază şi el opiniei istoricilor religiei care spun că „Pavel, şi nu Iisus, ar fi fost adevăratul fondator al creştinismului. Fără el (fără Pavel), mişcarea lui Iisus ar fi dispărut precum celelalte secte mesianice din cadrul iudaismului”" (p. 181). Şi, la fel, în ceea ce priveşte religia creştină, după ce vorbeşte despre Hristos, despre prima Biserică creştină şi despre persecuţii, ajungând la momentul Constantin cel Mare, Richard Holloway afirmă că ,am fi naivi dacă am considera mişcarea lui Constantin (îmbrăţişarea creştinismului) drept o convertire spirituală la credinţa în Iisus. Vorbim despre un politician calculat (adică împăratul Constantin cel Mare), care hotărâse deja că creştinismul putea fi liantul ce avea să ţină imperiul său unit: o Biserică universală ataşată unui imperiu universal" (p. 189). Se poate astfel observa o raliere a lui Holloway la linia de gândire a unui creştinism care se vrea cât mai raţional cu putinţă, mai ales pentru omul secolului XXI, iar aceasta în detrimentul 
trăirii şi al sentimentului. La fel precum s-a văzut şi în cazul Sfântului Apostol Pavel, Holloway nu spune ceva nou în legătură cu Constantin cel Mare şi cu motivele convertirii sale la creştinism, ci doar îmbracă într-o nouă formă de exprimare idei al căror fond este mai vechi.

Următoarele trei capitole din carte, 22-24, sunt dedicate ultimei mari religii universale apărută pe scena istoriei: islamul. Cele trei aspecte din islam asupra cărora se concentrează Holloway în prezentarea acestei religii sunt: Mahomed este ultimul profet, islamul cere supunere deplină numai lui Allah, pentru a transmite mesajul profetului Mahomed în toată lumea, supuşii lui Allah nu trebuie să se reţină de la luptă, ba chiar, din contră, ea este tocmai indicată în această privinţă. Într-un mod surprinzător de succint, Holloway face trecerea de la Islam la Reforma Protestantă prin intermediul a doar două capitole din cartea sa, respectiv capitolele 25 şi 26. În capitolul 25 se axează pe problematica existenţei iadului, chestiune văzută, în special, atât prin prisma islamismului, cât şi prin cea a Bisericii Romano-Catolice. Conform lui Holloway, în decursul Evului Mediu, deşi islamul, prin intermediul Coranului, a fost primul care a descris într-un mod foarte macabru chinurile iadului, spre deosebire de Biblia creştină, totuşi, în Evul Mediu, „Biserica Romano-Catolică a devenit cel mai mare patron al artelor... mai presus de orice altă formă de artă, adora picturile. Ceea ce însemna că, în vreme ce musulmanii nu puteau descrie iadul decât prin cuvinte, creştinii puteau să-1 şi picteze" (p. 223). Frica de iad, printre altele, a fost utilizată de Biserica Medievală Apuseană în scopul manipulării adepţilor ei ca să cumpere indulgenţe, adică iertări ale păcatelor. Aceasta a fost scânteia care a aprins focul Reformei Protestante în secolul XVI, capitolul 26 concentrându-se pe debutul religiei în Epoca Renaşterii.

Pe parcursul următoarelor cinci capitole, 27-31, Holloway analizează fenomenul Reformei Protestante în Europa, în secolele XVI-XVII, însă, din nou, la jumătatea acestei analize, rămânând fidel metodei istorice cronologice de abordare a istoriei religiei pe care şi-a propus-o în această lucrare. În capitolul 29 se ocupă de un alt fenomen religios reformator care s-a petrecut în acelaşi timp, dar 
într-o altă parte a lumii, la mare depărtare de Europa: India. Aici și acum a luat naştere religia sikh, o combinaţie între hinduism şi islamism, iar Guru Nanak, întemeietorul acesteia, este considerat de către Holloway echivalentul oriental al reformatorului religios creştin occidental Martin Luther. Deşi, în mod surprinzător, Holloway nu pomeneşte deloc în lucrarea sa şi despre reformatorul francez Jean Calvin, nu trebuie să ne mire faptul că, pe de altă parte, vede în Biserica Anglicană calea confesională de mijloc dintre Biserica Romano-Catolică şi Bisericile Protestante apărute în Europa în secolul al XVI-lea, iar capitolul 31 este dedicat în exclusivitate apariţiei protestantismului în Scoţia, ţara natală a lui Richard Holloway.

În ultima parte a cărţii, începând cu capitolul 32 şi până la ultimul capitol al acesteia, capitolul 40, Holloway, mergând în pas cu istoria mondială modernă şi profană, acordă un loc tot mai important pe scena istoriei religioase Lumii Noi descoperită de Christofor Columb la sfârşitul secolului XV: America. Totuşi, trebuie precizat faptul că tratează din acest punct de vedere numai America de Nord, începând cu triburile de indieni băştinaşi, cu sosirea puritanilor şi a quakerilor în SUA, continuând cu cele trei denominaţiuni creştine de natură eshatologică apărute în SUA în secolul XIX: Mormonii (Biserica Sfinţilor Ultimelor Zile), Adventiştii de Ziua a Şaptea şi Martorii lui Iehova, dar şi cu unele denominaţiuni creştine americane ce îşi atestă originea într-o simbioză, mai mult sau mai puţin credibilă, cu medicina şi cu ştiinţa, precum Biserica Ştiinţei Creştine şi Biserica Scientologică. Un mare neajuns al cărţii lui Holloway, referitor la continentul american, este acela că nu explorează religiile precolumbiene, din zona centrală şi sudică a acestui continent, dar nici religiile populaţiilor tribale din America de Sud.

În ultima parte a cărţii sale, R. Holloway se ocupă şi de tema ecumenismului religios, în opinia lui ,religia cu cel mai pregnant caracter ecumenic nu-şi are originile în hinduism, ci în islamism. Religia respectivă se numeşte babism şi s-a născut în Persia, în anul 1844 , adică pe teritoriul de azi al Iranului” (p. 328). În ultimele pagini, Holloway nu ocoleşte subiecte religioase sensibile şi de 
actualitate, precum conflictul dintre ştiinţă şi religie, dintre fundamentalismul religios şi raţionalismul ştiinţific, aducând ca exemplu practic, în acest sens, Procesul Maimuţelor din America interbelică. Desigur, nici subiectul războaielor religioase ori al războaielor sfinte, astăzi un subiect tot mai mediatizat, mai ales în zonele de conflict orientale, nu scapă nici el de analiza lui Holloway. În ultimul capitol al cărţii, autorul ne prezintă fresca occidentală, e adevărat, a universului religios contemporan, un univers în care ideile iluministe şi sentimentele religiose au dat naştere unei noi forme de religie: umanismul secular (p. 355-358).

Cartea lui Holloway, cu un grad ridicat de nonconformism religios, în general, şi creştin, în special, este o lectură accesibilă oricărui cititor interesat de a cunoaşte istoria fenomenului religios din cele mai vechi timpuri şi până în zilele noastre, într-o variantă rapidă şi neîncâlcită într-un limbaj de specialitate, cu note de subsol nenumărate şi colosale sau care să dea dovadă de un subiectivism religios sau confesional vizibil încă de la primele pagini ale acesteia. Altfel spus, pe Holloway îl poate citi şi un teolog cu studii aprofundate în domeniu, dar şi un simplu credincios profan, fără astfel de studii. În concluzie: o lectură plăcută, utilă şi facilă.

\section{Drd. Alexandru Nicolae Agignoaei} Facultatea de Teologie Ortodoxă din Alba Iulia 